\title{
"Let Us Give New Names to the Stars": F. R. Scott, Dorothy Livesay, and the Power of Poetry to Move beyond Labels
}

\section{Astrid Lohöfer}

\section{CpenEdition}

\section{Journals}

Electronic version

URL: https://journals.openedition.org/ces/5279

DOI: $10.4000 /$ ces. 5279

ISSN: 2534-6695

\section{Publisher}

SEPC (Société d'études des pays du Commonwealth)

\section{Printed version}

Date of publication: 1 September 2013

Number of pages: 69-79

ISSN: 2270-0633

\section{Electronic reference}

Astrid Lohöfer, "'Let Us Give New Names to the Stars": F. R. Scott, Dorothy Livesay, and the Power of Poetry to Move beyond Labels", Commonwealth Essays and Studies [Online], 36.1 | 2013, Online since 16 April 2021, connection on 22 July 2021. URL: http://journals.openedition.org/ces/5279; DOI: https://doi.org/10.4000/ces.5279

\section{(c) (i) $\ominus$}

Commonwealth Essays and Studies is licensed under a Licence Creative Commons Attribution - Pas d'Utilisation Commerciale - Pas de Modification 4.0 International. 


\section{"Let Us Give New Names to the Stars": F. R. Scott, Dorothy Livesay, and the Power of Poetry to Move beyond Labels}

The argument of this paper is based on the philosophical view that by changing the words and labels we use, we can discover new ways of thinking, feeling, and understanding. Lyric poets, especially during the Modernist period, often tried to convey profound ethical insights through innovative linguistic forms, an aspect that recent ethical criticism has tended to ignore. Analyzing exemplary works by two Canadian Modernist poets, I argue that an adequate appreciation of the relationship between ethics and lyric expression needs to take into account the world-disclosing potential of poetic language, i.e., the power of poetry to transcend traditional labels and to reveal aspects of the world that usually remain unexplored.

It is a common view in contemporary philosophy that language determines our consciousness and that we can change the way we feel and think by changing the words we use (Losonsky 38; Hallett 1-12). The aim of this paper is to show that this idea is central to the relationship between ethics and Modernist poetry, which, despite the recent ethical turn in literary studies, has received little critical attention to date. The large majority of studies in the field of ethical criticism confine themselves to the analysis of narrative prose, implicitly or explicitly associating the lyric genre in general, and the period of Modernism in particular, with aestheticism or lack of social significance. In contrast to this, I claim that the reasons for this striking disinterest of ethical critics in (Modernist) lyric poetry do not lie in the fact that this type of literature is per se unethical, but rather in definitional problems with the concepts of ethics and literary language. Consequently, I focus on the process of labelling and transcending labels on two different levels. First, I briefly discuss the theoretical notions that are used in current ethical criticism to explore the relationship between literature and ethics. In contrast to the dominant paradigms of subordinating either aesthetic phenomena to ethical content or the concept of ethics to textual experience, I focus on the interrelatedness of ethics and aesthetics by considering the linguistic creativeness of literature as a means of ethical world-disclosure, i.e., as a possible means of breaking the constraints of institutionalized discourse and of opening up new insights and ways of thinking. In a second step, I argue that the belief in the power of poetic language to move beyond normative labels plays an important role in the poetics of Canadian Modernism, the ethical and political implications of which have been increasingly recognized in recent years. In order to substantiate this claim, I discuss exemplary poems by F. R. Scott and Dorothy Livesay, who have significantly contributed to the development of Modernism in Canada. Both poets are usually read as examples of committed Modernist writers, while their aesthetic strategies are often overlooked. In my readings, I demonstrate how Scott's and Livesay's hope of gaining more expansive perspectives on ethical issues is closely related to a search for new metaphors and forms of expression.

Philosophers usually define ethics as the systematic reflection on existing norms and values and distinguish this term from the notion of morality, which denotes the accepted code of behaviour in a particular society (Clarke 307-8; Harpham 397). Within the domain of literary studies, there are two major strands of research which propose 
very different understandings of the nature of ethics and - related to this - of the role of language in ethical criticism: the so-called "Neo-Aristotelian" or "Neo-Humanist" approach, the main representatives of which are Wayne Booth and Martha Nussbaum, and the Postmodernist approach, which is advocated chiefly by Paul de Man and J. Hillis Miller. Neo-Aristotelian ethical critics assume that literary reading shapes our norms and values by providing us with (positive or negative) role models of moral behaviour. No less so than living persons, they argue, fictional characters can become our friends and influence our attitudes and feelings (Booth, Company 169-98). According to this view, literature functions as a tool of ethical reflection that is even more effective than philosophy, because in contrast to the rational method of philosophical writing, the fictional nature of literature incites readers to identify with the lives of other people, to share their problems and concerns, and to draw on these insights in case they come into a similar situation in their own lives. According to Martha Nussbaum, "it is [...] as readers of novels that we should approach the social choices before us, trying [...] to consider [...] our fellow human beings with the wonder and the generosity that this imagination promotes" ("Literary Imagination" 246). Critics have pointed out that this approach to literary ethics should be called moral rather than ethical criticism (Arizti and Martínez-Falquina xii), since it displays the hope that literature can provide access to universally-binding moral standards by offering readers, as Booth puts it, "an extensive list of judgments about what constitutes defensible and indefensible human behaviour" ("Ethical Criticism" 26). Related to the Neo-Aristotelian understanding of ethics is a conception of literary language that postulates a one-to-one correspondence between words and real-world entities. For Booth and Nussbaum, the written words on the page resemble transparent window panes through which one can see, and identify with, people and their actions in a clear and direct way. As a result, questions related to the formal characteristics of a text tend to be ignored by these critics, since they consider the ethical benefit of a literary text to reveal itself primarily on the level of content.

The second type of ethical criticism is informed by Postmodernist theory and focuses on the level of literary form by conceptualizing the ethics of literature as based in the very materiality of language itself. In this approach, ethics is not understood as a language-independent domain of human experience that can be accessed through literary texts, but as "a discursive mode among others," (de Man 206) which is subject to the same problems of understanding, interpretation, and evaluation as any other act of communication. Therefore, Postmodernist scholars are convinced that the ethical impact of literature lies chiefly in the way it questions deeply held assumptions about the transparency of language, which, for the Neo-Aristotelians, is simply a given. As a consequence of attentive deconstructive reading, Postmodernist critics argue, readers will become aware of the multiple contradictory layers of a text, and thus of their own final inability to read and understand (Miller 48). The humble acceptance of the universal impossibility of reading is taken to be ethical in itself, because this experience affects literary interpretation no less than ethical decision-making in real life. As J. Hillis Miller puts it: "The failure to read [...] is a universal necessity, one moment of which is that potentially aberrant form of language called ethical judgment or prescription" (51). It is obvious that the Postmodernist conception of both ethics and literary language differs very much from that of the Neo-Aristotelians. Language is not seen as a transparent window on reality, but as a screen with nothing behind, a self-enclosed system of signs that refer less to real-world 
entities than to their own internal relations and ambiguities. As a result, ethics is no longer located in the world outside of texts - since there is nothing outside of texts (Derrida 227) -, but re-defined as the textual experience of epistemological uncertainty. A major strength of Postmodernist ethical criticism is that it takes into account the difficulties related to the act of reading, thus avoiding the pitfalls of an unquestioned assumption of real-world presence in literary texts. The serious problem of this approach, however, is that it is based on a purely theoretical notion of ethics, which is no longer equated with a concrete reflection on specific values, but with the abstract insight into the general impossibility of universal truth. ${ }^{1}$ As Robert Eaglestone summarizes the predicament of current ethical criticism, the Neo-Aristotelian approach "offers a convincing case for Aristotelian ethics, but not a convincing method of dealing with the problems of texts," while Postmodernist criticism "cannot offer a convincing account of ethics because [it] is acting on the presupposition that ethics are a linguistic category" $(92,94)$.

Moreover, both these conceptions of ethics and language are not entirely satisfactory in terms of their applicability to the genre of lyric poetry. Seen from the angle of Neo-Aristotelian criticism, the genre-specific characteristics of the lyric - increased self-referentiality, a strong focus on language, and a comparative lack of action and plot - seem to be largely incompatible with an ethics-based approach to literary analysis. Not surprisingly, the writers that Martha Nussbaum cites as examples of ethical insignificance are Modernist poets, whose complex style is an obstacle to readerly identification ("Exactly and Responsibly" 75-6). Accordingly, the few recent works that do analyze the ethical effects of lyric poetry (e.g. Woods; Jenkins; Williams) generally follow the Postmodernist argument that literary ethics implies an increased awareness of the nature of human language. Most of these studies draw on the philosophy of Emmanuel Levinas, who maintains that the conscious engagement with language is a primordially ethical experience which, in his theory, resides less in the acceptance of contingency or undecidability than in an unmediated encounter with alterity (16-20). Although this emerging line of research has made an important contribution to the recognition of poetry's ethics, it faces the same problems as Postmodernist ethical criticism in general: first, it relies on a highly abstract understanding of ethics that is far removed from particular issues of moral philosophy, and second, it tends to bypass the particular ethical concerns of individual texts by making very generalizing statements about the inherent ethicality of language as such.

In my view, a more nuanced understanding of the ethics of poetry necessitates an approach to ethical criticism that takes into account the role of literary language and aesthetic experience without having to redefine ethics as an abstract epistemological category. I propose to retain the original sense of ethics as a reflection on moral values and to rethink the function of literary language by moving beyond the dualism between language as a transparent medium (as in the Neo-Aristotelian approach) and language as a site of undecidability (as advocated by the Postmodernists). Such an alternative conception of language is developed by Martin Heidegger and Paul Ricœur, who consider the linguistic creativeness of literature as a means of world-disclosure, which opens

1. The same holds true for other Postmodernist approaches, such as pragmatist ethical criticism as advocated by Richard Rorty or Richard Shusterman, which defines the ethics of reading as the recognition of the contingency of language, while claiming that this insight constitutes a decisive step towards critical self-awareness and liberal thought (Rorty 44-69; Shusterman 236-61). 
up new insights and perspectives that cannot be expressed by ordinary speech. Heidegger, for instance, relates poetic experience to the notion of aletheia, or unconcealment. For him, artworks in general, and lyric poems in particular, convey a specific form of truth by revealing aspects of reality that usually remain veiled or hidden. Considering language as the "House of Being," he claims that the unworn and innovative language of poetry invites us into a truer, more authentic relationship with the world and ourselves (216). In a similar vein, Paul Ricœur emphasizes the creative dimension of literary language by comparing poetic texts to extended metaphors that move beyond conventional labels and return language to its original, evocative power. Like scientific models, he argues, the language of literature is able to provide a progressive approximation to new insights that cannot be paraphrased in everyday speech without a significant loss of meaning (310). Thus, instead of equating literary language with a straightforward representation of reality or, on the contrary, with a self-referential system of signs, Heidegger and Ricœur conceptualize it as a dynamic tool of reaching alternative views of the world that resist dominant ideologies. This view of language, I suggest, allows us to no longer consider lyric poetry as either incompatible with ethics (because it resists readerly identification) or as inherently ethical (because it is cognitively complex), but to analyze the various interrelations between the linguistic innovativeness of the lyric genre and the ethical questioning of established moral codes.

In the following, I exemplify these theoretical considerations by examining the nexus of ethics and poetic language in the works of F. R. Scott and Dorothy Livesay, two key figures of the Modernist movement in Canada, who both rely on an understanding of language as described by Heidegger and Ricœur. After Robert Kroetsch's famous statement that "Canadian literature evolved directly from Victorian into Postmodern," (1) the rise of cultural modernity in Canada has been neglected by literary criticism for a long time. In recent years, however, an increasing number of scholars have focused on the nature and evolution of the Canadian Modernist movement. Taking the latter as an example of what Dean Irvine calls "marginal modernisms," (Introduction 4) i.e., of Modernist tendencies outside the European canon, these critics hope that the study of decentred and belated forms of Modernist writing might put into question common assumptions about Modernism in general (Kronfeld 5). One major aspect of this reinterpretation of Modernist literature concerns its relationship to ethics and (leftist) politics, ${ }^{2}$ which has been frequently ignored because of the widespread association of Modernism with cultural and political conservatism or aesthetic detachment from public life. While the recent emphasis on ethics in Canadian Modernist studies indeed makes a valuable contribution to challenging aestheticist conceptions of Modernism, this approach faces the danger of becoming polarized in the opposite direction, because it views literature chiefly through the lens of social commitment and thus tends to lose sight of the aesthetic dimension of the works under discussion.

A strong polarization between ethics and aesthetics takes place, for instance, in the scholarly reception of the poetry of F. R. Scott. Critics have either highlighted Scott's achievements as a lawyer, politician, and writer of engaged literature (e.g. Djwa and Macdonald), or argued that his preference for ambiguities and complex imagery points to an inability or unwillingness to make clear ethical choices (e.g. Campbell). As Bart Vau-

2. See, for instance, the essays collected by Dean Irvine in the special issue of Canadian Literature 209 (2011) on the "Spectres of Modernism." 
tour rightly points out, however, that "The academic bifurcation of Scott's poetry and politics is more a symptom of the structural limitations of disciplinary critical practice than it is about a strict division in Scott's mode of production" (68). Vautour's claim is confirmed by Scott's own confession that "I never felt the slightest contradiction between [...] politics and writing poetry, because the politics I professed and practiced was to me a creative idea about society, and any creation is art" (Scott in Vautour 68). As this statement shows, Scott considers the faculties of imagination and creativity as crucial to the development of social consciousness. In several of his early poems, such as "Sonnet" or "The Trappists," he discusses the relationship between aesthetic experience and active participation in the world's affairs, suggesting that one should not subordinate one of these two concepts to the other, but try, as he puts it in "The Problem" (Collected Poems 234) to "reach a golden compromise" (31) between art and life. In "Overture" (Collected Poems 87), this ideal is subtly evoked through the use of imagery, in that the speaker's explicit emphasis on the necessity to change existing political realities is interwoven with expressions from the semantic field of music. The first two stanzas describe the performance of a Mozart sonata, albeit only in terms of visual impressions, so that the concert is ultimately reduced to an entertaining stage show, in which the focus is not on music and its emotional content, but on the atmosphere in the concert hall, the outward appearance of the pianist, and the virtuosity of his playing. In the second part of the poem, a sudden accumulation of musical terms, such as “overtures," (12) “octave," (15) or "crescendo," (16) implies that the speaker undergoes a transformation from a shallow, ignorant and unmusical being to an active, attentive, and sensitive listener who is open to the specific effects of a particular art form, and, in consequence, to art's power to unlock new ways of perceiving the world. When "the tissue of art" - that is, of art as superficial and escapist entertainment - "is torn / With overtures of an era being born," (11-2) the view opens to "a window / Beyond whose curtain grows a world crescendo" (15-6). As much as art has to remain close to ethics in order to maintain its critical relevance to society, Scott's poem insinuates that the ethical impact of a work of art is inextricably linked to its specific aesthetic properties.

While "Overture" is concerned with the intersection of ethics and art in general, "Poetry" (Collected Poems 133) reflects upon the ethical force of lyric art in particular. The opening claim that "Nothing can take its place" (1) is based on the idea that poetry has the unique ability to transform words into vivid imagination, thus producing meanings and perspectives that remain hidden in everyday discourse. In Scott's view, this can be achieved by forming new mental images through the connection between previously unrelated concepts, such as the linking of the word "ostrich" to the Canadian Prime Minister Mackenzie King in stanza one, which denounces the latter's liberal policy as being blind to the hardships of the masses. On the other hand, Scott believes that poetic language is particularly suited to the task of restoring words to their essential meaning by stripping them of common - and morally questionable - connotations that have been accumulated over centuries, for instance, the association of the most profound human experiences such as love and death with profit and financial gains:

And if I write "holocaust," and "nightingales,"

I startle the insurance agents and the virgins

Who belong, by this alchemy, in the same category,

Since both are very worried about their premiums. (5-8) 
While poetry challenges our common expectations in words and meanings, ordinary speech is trapped in the narrow framework of historical growth and usage, as Scott deplores in another poem:

Let us give new names

To the stars.

What does Venus mean

Or Mars? ("New Names," Collected Poems 40, 1-4)

Comparing the words of everyday language to a wrongly placed traffic sign blocking a road that is actually passable, the speaker of "Poetry" refuses to be discouraged by these seeming obstacles of thought and searches for new forms of expression, a process that he equates with a train ride taking him towards new and unexplored realms of experience: "Sometimes I have walked down a street marked No Outlet/ Only to find that what was blocking my path / Was a railroad track roaring away to the west" (10-2). Evoking the Heideggerian idea that the language of poetry constitutes an autonomous force that speaks from within itself and compels us to listen to its appeal (Heidegger 213-4), Scott's poet-narrator finally comes to the conclusion that "Not even the decline of reading [...] / Can crush the uprush of the mushrooming verb / Or drown the overtone of the noun of its own" (133). In sum, many of Scott's poetological works mirror his belief that art and poetry are primary means of questioning conventional norms and labels, insofar as a poet's "innovations of style [...] may lead to a new dimension of thought and feeling” (Scott in Trehearne 141).

This hope is especially evident in Scott's nature poems, in which the values of civilization and progress are put into perspective through unexpected juxtapositions and creative metaphors. In "Mount Royal," (Collected Poems 59) the development of the human race is compared to that of extinct sea creatures, the remains of which are hidden in the soil of Montreal's highest point, Mount Royal: "Where flowers march, I dig these tiny shells / Once deep-down fishes safe, it seemed, on sand" (7-8). Fascinated by these relics of prehistoric times, the speaker imagines how the peak on which he is standing was once a desert island surrounded by the waters of the ocean (5). Considering that the world is in a Heraclitean flux (1-2), he realizes that if a new ice age were to come, mankind would face the same fate as the fishes, which seemed to be safe in the depths of the sea, until the rising of the very mountain that made human life possible in this area led to their final extinction. "Elect your boys, lay out your pleasant parks, / You gill-lunged, quarrelsome ephemera!" (21-2), the speaker grimly addresses the inhabitants of the earth, "The tension tightens yearly, underneath, / [...] And oceans wait their turn for ice or streets" $(23,25)$. In accordance with the poetological insights expressed in "Poetry," "Mount Royal" creates an unaccustomed view on reality by linking two initially unrelated concepts: the metaphorical overlap between the vanished fish and the "gill-lunged" human species invites readers not only to rethink the aims and ends of human action in the face of the grander scheme of geological time, but also to develop an attitude of humility towards the natural world and its ephemeral, transitory state. A similar technique is used in "Lakeshore," (Collected Poems 50) in which the object that initiates the poet's chain of associations is not a fossil, but the graceful movement of living fish swimming in a lake. Merging with the image of "naked swimmers," (23) who are "Drawn to their prehistoric womb," (24) the fish become a symbol of primordial bliss and energy, in the light of which human evolution to Homo sapiens appears as a regression, since 
"Tied to a horizontal soil / The floor and ceiling of the soul," (43-4) we have only risen "Upon our undeveloped wings / Toward the prison of our ground" (36-7). In "Stone," (Collected Poems 54) the negative aspects of human progress are condensed in the image of a stone, which merges again two separate ideas: the stone is not only a witness of the oldest eras of the world - "Its smoothness / is an icy history" - (5-6) but also an essential tool of human civilization, in that it has served over thousands of years as a construction material for buildings of all types, from tombs (1-2) over churches (9-10) to prisons (14-5). By pointing out that the same substance that is used for the erection of a house of God is also contained in tombs and prison walls, the poem suggests that humankind is not only characterized by noble aspirations towards divine knowledge, but also by mortality and a proclivity for violence and subjugation. The latter aspect finally culminates in the vision of bursting atoms of stone falling on Hiroshima (16-7) which closes the circle from the prehistoric beginnings of the planet to the end of history through nuclear destruction. The surprising associations between disparate images and levels of meaning in Scott's nature poems illustrate how the metaphorical richness of lyric language is able to transcend ingrained patterns of thought, for example, about the endless possibilities of human progress. Whether the unearthed relics of a prehistoric fish in "Mount Royal," the primordial underwater world in "Lakeshore," or the nuclear explosion in "Stone," Scott's complex and evocative imagery vividly challenges man's supremacy over nature and stimulates an ethical reflection on our responsibility towards the planet and future generations.

The striving for new dimensions of thought and feeling is also evident in the works of Dorothy Livesay, one of Canada's most celebrated women poets. As in the case of Scott, critics have frequently noted a dichotomy between Livesay's "public" poetry, which explicitly address issues of social and political relevance, and her "private" love poems, which are usually read as subjective and primarily lyrical expressions (Denham 88). I argue, however, that Livesay's exploration of lyric writing in her love poetry has wide-ranging ethico-political implications concerning the status of women in society and their experience of selfhood and intimate relationships. Seeking public recognition as a woman writer in a period dominated by male voices, Livesay was committed to a lifelong struggle against gender stereotypes, which, in her view, forge a gap between the sexes and limit the ability of women to develop their skills and talents. In "Bartok and the Geranium," (Collected Poems 236) for instance, it is less the inherent incompatibility of the natures of man and woman than the social construction of gender roles that turns out to be the source of misunderstanding and frustration between the sexes. Essentially, the two protagonists, which are associated simultaneously with the principles of male and female and with the realms of culture and nature, embody the complementary qualities of passivity and activity, matter and energy, brightness and darkness, thus appearing as mutually enriching forces, which "in this room, this moment now / [...] together breathe and be" (24-5). At the same time, however, this ideal complementarity between man and woman is undermined by the subtle insertion of traditional gender clichés that relegate women to subservient and passive roles - "Whatever falls / She has no commentary / Accepts, extends" - (6-8) and men to stereotyped male attitudes, such as selfishness, aggression, and hubris - "He [...] / Soars beyond sight/Then hurls, lost Lucifer / From heaven's height" (27-30). At the end of the poem, the geranium is left 
alone by Bartok, and both return to their respective spheres of domesticity and public performance, not being able to develop a true and lasting understanding of each other.

In order to overcome the socially imposed division between man and woman as problematized in "Bartok and the Geranium," Livesay sees the need to free language from gender biases and other dichotomies of Western rational thought. Instead of taking part in a search for gender-free and feminist vocabulary, her ambitious goal is to achieve a synthesis of male and female by using everyday words, which she attempts to detach from their usual meanings and mutual oppositions. In many of her poems, this aim is expressed through symbols of silence counteracting the human tendency towards labelling, classifying, and "passionate naming" ("Winter Ascendant," Ice Age 52-3, 22). Focusing on silent life-forms, such as flowers, plants, and trees, Livesay suggests that by way of introspection and active receptivity to the impulses of language, one can move beyond the borders of conventional word use and make "meanings bound / rebound" ("To Be Blind," Ice Age 72, 6-7) in order to "Deliver these ears / from voices / bondages of language" ("Windows," Ice Age 65, 19-21). In "Sunfast," (Collected Poems 286-7) the speaker leaps into a new mode of consciousness, in which distinct or even contrary concepts merge into a holistic unity: rapidity and firmness, up and down, eating and sunbathing, sunrays and grass, the sound of a lawnmower and the purring of a cat. This experience is initiated by a creative play with language, which explores productive morphological processes, etymological linkage between words, and the revelatory potential of homophony: the word coinage "sunfast," for instance, combines "sun" with "fasten," "unfasten," and the various meanings of "fast," thus uncovering the hidden correspondences between different sensory phenomena and allowing the speaker to break free from self-imposed intellectual restrictions that prevent one from seeing the complex and multifaceted nature of things. A similar idea is explored in "Variations on a Tree," (Call My People Home 18-9) in which the roots of a tree as the symbol of the speaker's linguistically articulated consciousness become detached from the confining ties of historically and socially determined contexts and find a new hold in the sky, where they are "Wading in pools of blue" (16) and "Play[ing] football with the moon" (18). As in "Sunfast," top and bottom are reversed, and the resulting liberation of thought manifests itself in a language that increasingly dispenses with the rules of semantics, syntax, and punctuation. After being no longer "confined to a narrow place," (1) the tree can eventually "love and grow" (41); it not only engages in a relationship with other trees by forming "A roof of hands / Against sky fall," (45-6) but also embraces a more authentic self, which is open to change and transformation.

A new sense of identity is also the theme of "On Looking into Henry Moore," (Collected Poems 236) where a creative exploration of poetic language leads to the emergence of a complex, androgynous concept of self transcending gender labels and socially ascribed roles. The first stanza of the poem probes into the semantic relations between words that differ only in one or two phonemes, thus evoking the same mixture of stability and excitement that is conveyed by the compound "sunfasten":

Sun, stun me, sustain me

Turn me to stone:

Stone, goad me, gall me

Urge me to run. (1-4) 
Intertwined like the curves and shapes of a sculpture by Henry Moore, the sounds of the words create a synthesis between contradictory meanings that are at the centre of the poem's main vision: the initial transition from motion to rest, from astonishment to sustainment, from sun to stone, is merged, through the alteration from "stone" via "goad" to "gall," with the idea of being stripped to the bones and bringing out one's innermost self. In contrast to "Bartok and the Geranium," where opposing categories such as passivity and activity result in an unbridgeable gap between the two sexes, the speaker succeeds in finding "Passivity in fire / And fire in stone," (6-7) because she forces herself to "Take off this flesh, this hasty dress," (23) and to look behind the surfaces of mere appearance. Similar to one of Moore's reclining figures, in which breast- and penis-shaped elements constitute complementary forms that fit into each other, the speaker's newly-gained identity combines "Woman in man, and man in womb," (26) thus replacing her former "half-self" (24) by "one unit," (25) which can "rise alone / Self-extending and self-known" (9-10). By letting language flow freely and evolve, the protagonist of "On Looking into Henry Moore" becomes able to discover "another / dimension behind our learned / word patterns" ("For the New Year," Ice Age 9-11) and to achieve an androgynous union of masculinity and femininity, agency and passivity, self-sufficiency and intimate relationship which transcends the gender binaries that negatively affect the characters and partnerships portrayed in many of Livesay's other works.

To conclude, the ethics and poetics of both above-discussed Canadian Modernists are based on the premise that by opening oneself to the sensuous and evocative power of lyric poetry, one can stimulate the imagination into unfamiliar, precognitive modes of awareness that extend beyond conventional labels and judgments. While F. R. Scott wrote a number of significant poems that question entrenched views of humankind's superiority over nature, a large part of Dorothy Livesay's work is dedicated to the struggle against gender stereotyping, which enforces a binary opposition between men and women instead of emphasizing the basic equality, unity, and complementarity of male and female forces. Both authors are convinced that fresh perspectives on a particular ethical issue can be gained by placing common metaphors and concepts into new contexts in order to challenge taken-for-granted meanings that circulate in everyday life. Moreover, they believe that this process of critical reflection is enhanced by the specific ability of lyric language to focus on the sounds and etymological resonances of single words and to unfold, as Scott puts it, "the overtone of the noun of its own." In their view, the ethical potential of literature is not only located in the explicit "message" of a written work, but also, and above all, in a creative use of language that produces new images and connections between words and compels readers to re-think established categories of thought. An analysis of Scott's and Livesay's understandings of the relationship between ethics and aesthetics impacts not only on common conceptions of (canonical and non-canonical) Modernism, but also on current debates about the ethical implications of literary experience. Whereas the Neo-Aristotelian method of ethical criticism neglects aspects of language and form and is, therefore, hardly applicable to highly language-centred types of writing such as poetry or Modernist literature, Postmodernist theories tend to reduce the notion of ethics to a purely textual or linguistic phenomenon, thereby bypassing the question of how individual works of literature invite an ethical engagement with concrete moral and social values. In order to be sen- 
sitive to the particularities of aesthetic production without separating the concept of ethics from that of moral philosophy, I have proposed in this paper an approach to ethical criticism that overcomes the dualism of language-as-instrument and languageas-object by following Heidegger's and Ricœur's treatment of poetic language as a site of ethical world-disclosure - an idea that also underlies the works of Dorothy Livesay and F. R. Scott as two important representatives of Canadian Modernism. By examining the nexus of Modernist poetics, linguistic innovation and ethical reflection, I hope to have shown that the process of challenging labels and preconceptions is crucial not only to the connection of ethics and literature, but also to the field of academic discourse, where prejudices such as the seeming irrelevance of a whole literary genre to a particular field of discourse can arise from the unquestioned acceptance of key theoretical terms and definitions.

Astrid LOHÖFER

University Montpellier III/Philipps-Universität Marburg

\section{Works Cited}

Arizti, Bárbara, and Silvia Martínez-Falquina. Introduction. On the Turn: The Ethics of Fiction in Contemporary Narrative in Ethics. Ed. Bárbara Arizti and Silvia Martínez-Falquina. Newcastle: Cambridge Scholars, 2007. ix-xxiii.

Bоотн, Wayne C. The Company We Keep: An Ethics of Fiction. Berkeley: U of California P, 1988.

—. "Why Ethical Criticism Can Never Be Simple." Ethics, Literature, Theory: An Introductory Reader. Ed. Stephen K. George. Lanham: Rowman \& Littlefield, 2005. 23-35.

Campbell, Wanda. "The Ambiguous Social Vision of F. R. Scott." Canadian Poetry: Studies, Documents, Reviews 27 (1990): 1-14.

Clarke, Paul Barry. "Ethics." Dictionary of Ethics, Theology and Society. Ed. Paul Barry Clarke and Andrew Linzey. London: Routledge, 1996. 307-20.

DE Man, Paul. Allegories of Reading. New Haven: Yale UP, 1979.

Denham, Paul. "Lyric and Documentary in the Poetry of Dorothy Livesay." A Public and Private Voice: Essays on the Life and Work of Dorothy Livesay. Ed. Lindsay Dorney, Gerland Noonan, and Paul Tiessen. Waterloo: U of Waterloo P, 1986. 87-106.

Derrida, Jacques. De la Grammatologie. Paris: Minuit, 1967.

DJwa, Sandra and R. St J. Macdonald, eds. On F. R. Scott: Essays on His Contributions to Law, Literature, and Politics. Kingston: McGill-Queen's UP, 1983.

EAgLestone, Robert. Ethical Criticism: Reading After Levinas. Edinburgh: Edinburgh UP, 1997.

HalLEtT, Garth L. Linguistic Philosophy: The Central Story. Albany: U of New York P, 2008.

Harpham, Geoffrey Galt. "Ethics." Critical Terms for Literary Study. Ed. Frank Lentricchia and Thomas McLaughlin. Chicago: U of Chicago P, 1995. 387-405.

Irvine, Dean. Introduction. The Canadian Modernists Meet. Ed. Dean Irvine. Ottawa: U of Ottawa P, 2005. 1-13.

—, ed. Spectres of Modernism. Special issue of Canadian Literature 209 (2011): 6-200.

Jenkins, Grant Matthew. Poetic Obligation: Ethics in Experimental American Poetry after 1945. Iowa: U of Iowa P, 2008.

Kroetsch, Robert. "A Canadian Issue." Boundary 2: A Journal of Postmodern Literature and Culture 3.1 (1974): 1-2.

KRonfeld, Chana. On the Margins of Modernism: Decentering Literary Dynamics. Berkeley: U of California P, 1996.

Levinas, Emmanuel. Autrement qu'être ou au-delà de l'essence. 1947. The Hague: Nijhoff, 1996.

Livesay, Dorothy. Call My People Home. Toronto: Ryerson P, 1950.

—. Collected Poems: The Two Seasons. Toronto: McGraw-Hill, 1972.

—. Ice Age. Erin: Porcépic, 1975.

Losonsky, Michael. Linguistic Turns in Modern Philosophy. Cambridge: Cambridge UP, 2006.

Heidegger, Martin. “'Poetically Man Dwells”.” Trans. Albert Hofstadter. Poetry, Language, Thought. New York: Perennial, 2001. 209-27. Trans. of "'Dichterisch wohnet der Mensch'." Vorträge und Aufsätze. 1951. Stuttgart: Klett-Cotta, 2009. 177-92. 
Miller, J. Hillis. The Ethics of Reading. New York: Columbia UP, 1987.

Nussbaum, Martha C. "The Literary Imagination in Public Life." Renegotiating Ethics in Literature, Philosophy, and Theory. Ed. Jane Adamson, Richard Freadman, and David Parker. Cambridge: Cambridge UP, 1998. 222-46.

-. "Exactly and Responsibly: A Defense of Ethical Criticism." Mapping the Ethical Turn: A Reader in Ethics, Culture, and Literary Theory. Ed. Todd F. Davis and Kenneth Womack. Charlottesville: UP of Virginia, 2001. 59-79.

Ricceur, Paul. La Métaphore vive. Paris: Seuil, 1975.

RoRTy, Richard. Contingency, Irony, and Solidarity. Cambridge: Cambridge UP, 1989.

ScotT, F. R. The Collected Poems of F. R. Scott. Toronto: McClelland and Stewart, 1981.

Shusterman, Richard. Pragmatist Aesthetics: Living Beauty, Rethinking Art. 1992. Boston: Rowman \& Littlefield, 2000.

Trenearne, Brian. Aestheticism and the Canadian Modernists: Aspects of a Poetic Influence. Kingston: McGillQueen's UP, 1989.

Vautour, Bart. "F. R. Scott and the Emergence of a Poetics of Institutional Critique." Canadian Poetry: Studies, Documents, Reviews 66 (2010): 68-86.

Williams, David-Antoine. "Tête-à-tête, Face-à-face: Brodsky, Levinas, and the Ethics of Poetry." Poetics Today: International Journal for Theory and Analysis of Literature and Communication 30.2 (2009): 207-35.

Woons, Tim. The Poetics of the Limit: Ethics and Politics in Modern and Contemporary American Poetry. New York: Palgrave, 2002. 